\title{
Diagnostic value of histopathological examination results obtained during screening of patients with diagnosed atypical hyperplasia
}

\author{
Jakub Malinowski ${ }^{1}$, Miłosz Wilczyński ${ }^{1}$, Adam Depta², Andrzej Malinowski ${ }^{1}$ \\ ${ }^{1}$ Department of Operative Gynecology, Endoscopy and Gynecologic Oncology, Polish Mother's Memorial Hospital Research Institute, \\ Lodz, Poland \\ ${ }^{2}$ Department of Management, Lodz University of Technology, Lodz, Poland
}

\begin{abstract}
Vulvovaginal atrophy accompanied by lower urinary tract dysfunction related to low levels of estrogen and androgens is labeled as genitourinary syndrome of menopause (GSM). Although this condition affects most postmenopausal women worldwide, it seems to be underdiagnosed and undertreated. Women should be properly advised to choose an adequate treatment modality to improve their quality of life, sexual relationships and social activity. The aim of this article is to increase knowledge of GSM. The current treatment options, both hormonal and non-hormonal, are reviewed. Topical estrogen therapy still remains the gold standard, but the demand for individually tailored therapy is growing. New treatment modalities are continuously included in clinical practice. They should consider the whole personality of a woman as well as cultural and social factors. Further studies on GSM and on the effectiveness of various treatment options are necessary to achieve this purpose.
\end{abstract}

Key words: endometrial hyperplasia, atypical hyperplasia, endometrioid intraepithelial neoplasia, endometrial cancer.

\section{Introduction}

It is considered that the majority of endometrial cancers are a consequence of a developing hyperplastic disorder. Such disorders range from simple endometrial hyperplasia without atypia, atypical hyperplasia up to a well-differentiated endometrial cancer [1-6].

The 2014 WHO classification defines new types of endometrial hyperplasia:

- hyperplasia without atypia,

- endometrial hyperplasia/endometrial intra-epithelial neoplasia.

Endometrial hyperplasia is defined as excessive gland proliferation. Proliferating glands are not cytologically atypical, but irregular in shape and size with an increase in the gland-to-stroma ratio compared to a proliferating endometrium.

Cytologic atypia combined with hyperplasia can be defined as atypical hyperplasia (AH) or endometrial intra-epithelial neoplasia (EIN) [7]. Cellular atypia causes endometrial growth to progress to a precancerous condition [8, 9].

Epidemiological research suggests that the risk of progression to a neoplasm is low in hyperplasia without atypia ( $\leq 3 \%$ ), while an $\mathrm{AH}$ is closely related to subse- quent progression to an endometrial cancer or even an already present coexisting cancer $[10,11]$. Upon examination of postoperative tissue samples, coexisting endometrial cancers were found in $42 \%$ of women who were previously diagnosed with atypical endometrial hyperplasia [12-14].

Since 2017 the Polish Society of Gynecological Oncology has recommended a two-step diagnostic process when diagnosing and treating endometrial cancer. The first step includes a diagnosis that is made with an endometrial biopsy using methods such as standard diagnostic curettage, directed biopsy during hysteroscopy or an endometrial aspirational biopsy. The second step involves a cancer grading process based on the International Federation of Gynaecology and Obstetrics (FIGO) grading system supported by medical imaging and clinical evaluations.

While $\mathrm{AH}$ responds to treatment with progesterone, a hysterectomy with oophorectomy is recommended in post-menopausal women with cytological atypia due to a high probability of coexisting endometrial cancer or potential progression of the existing condition into a neoplasm [1, 4, 9]. Up to $50 \%$ of women who were biopsied and diagnosed with atypical endometrial hy- 
perplasia in fact have cancer [13]. The recommended method for performing a complete hysterectomy procedure is laparoscopy. This method has notable advantages such as shorter hospitalization, significantly lower postoperative pain and faster recovery compared with a laparotomic procedure. In pre-menopausal women the decision to remove ovaries should always be consulted, as it varies from patient to patient [16].

Identifying a complex $\mathrm{AH}$ during examination of endometrial tissue obtained during diagnostic curettage is of great clinical significance and impacts prognostic indicators [17]. Even when pre-surgery histopathological examination fails to identify $\mathrm{AH}$, the post-surgery examination shows the presence of cancer. It is often due to various problems that can occur during obtaining tissue from the uterine cavity $[16,17]$.

\section{Material and methods}

The goal of this study is to determine the frequency of endometrial cancer in tissue samples obtained after surgery in cases where $\mathrm{AH}$ was identified before surgery.

To study the correlation between histopathological results before and after surgery a Spearman's rank correlation coefficient and statistical significance $(p<0.05)$ methods were used.

The experimental group included 52 women who were hospitalized at the Department of Operative Gynecology, Endoscopy and Gynecological Oncology in Łódź from 2010 to 2017. Every member of the group was diagnosed with AH during uterine tissue histopathology examination or polyp removal. Methods used to obtain tissue for examination were chosen in accordance with patients' clinical condition: blind curettage of cervix and uterine cavity (21 patients), hysteroscopy followed by a directed biopsy (31 patients). In each case the procedure was performed under intravenous anesthesia.

Upon obtaining histopathology results a complete hysterectomy was performed in all qualified patients. Postoperative tissue was obtained and sent for a histopathological examination. All patients were hospitalized at the Department of Operative Gynecology, Endoscopy and Gynecological Oncology before and after surgery.

In addition to a histopathological examination of postoperative tissue in all endometrial cancer cases the following factors were considered: histological diversity, clinical grade according to FIGO and patient age.

Histopathology results obtained during initial screening were then analyzed and compared by retrospective analysis of patients' medical records. In all cases, histopathology examination and analysis took place at the Polish Mother's Memorial Hospital Department of Pathomorphology in Łódź.
Table 1. Indications for further diagnostics

\begin{tabular}{lcc}
\hline Indication for further diagnostics & $n$ & $\%$ \\
\hline Endometrial polyp & 17 & 32.69 \\
\hline Suspected endometrial hyperplasia & 13 & 25.00 \\
\hline Abnormal perimenopausal bleeding & 13 & 25.00 \\
\hline $\begin{array}{l}\text { Endometrial hyperplasia + abnormal } \\
\text { perimenopausal bleeding }\end{array}$ & 7 & 13.47 \\
\hline $\begin{array}{l}\text { Endometrial polyp + abnormal } \\
\text { postmenopausal bleeding }\end{array}$ & 1 & 1.92 \\
\hline $\begin{array}{l}\text { Abnormal postmenopausal bleeding, } \\
\text { uterine fibroids }\end{array}$ & 1 & 1.92 \\
\hline
\end{tabular}

\section{Results}

Endometrial polyps are the most frequent indication for further diagnostics (17 cases - 32.69\%). Indications for further diagnostics are included in Table 1 below.

Endometrial cancer was identified following a postsurgical tissue analysis in $88.46 \%$ (46 out of 52 patients) of patients. In 4 cases simple and complex endometrial hyperplasia was found (7.69\%). Other findings included 1 case of simple hyperplasia without atypia (1.92\%) and another single case of complex hyperplasia with atypia (1.92\%).

In the majority of cases (35 patients $-76.08 \%$ ) welldifferentiated cancers (G1) were found. Moderately differentiated cancer varieties (G2) were found in 10 patients $(21.75 \%)$ and one poorly differentiated variety was identified (2.17\%).

Uterine cancer grades according to the FIGO classification are shown in Table 2.

The median age among the 52 women from the experimental group was 58.5 (average: 57.38). The youngest patient was 35 years old when undergoing surgery while the oldest was 82 years old. Statistical significance of $p=0.01314$ was achieved between age and post-surgical tissue analysis results.

\section{Discussion}

The correlation between histopathological results from tissue obtained during initial screening and post-

Table 2. Uterine cancer spread grade as developed by FIGO in 2009

\begin{tabular}{lcc}
\hline Cancer spread grade & $n$ & $\%$ \\
\hline IA & 39 & 84.79 \\
\hline IB & 3 & 6.53 \\
\hline II & 1 & 2.17 \\
\hline IIIA & 1 & 2.17 \\
\hline IIIB & 1 & 2.17 \\
\hline IIIC1 & 1 & 2.17 \\
\hline
\end{tabular}


surgical diagnostic analysis is extremely significant due to its predictive value for further therapy. This can affect critical decisions in therapy such as the need for surgery and its potential scope.

Our own studies show that as many as $88.68 \%$ of 52 women with atypical endometrial hyperplasia (identified by histopathological examination of uterine tissue or polyp tissue) are diagnosed with endometrial cancer after surgery.

According to various publications, $\mathrm{AH}$ remains closely related to further progression into endometrial cancer, or even a previously existing neoplasm $[10,11]$.

In a study by Zhang et al. 222 patients with complex $\mathrm{AH}$ were examined. Post-surgical tissue examination results show 85 cases (38.3\%) of endometrial cancer - significantly less than identified in our own research [17]. Similar results were obtained by Trimble et al., where 289 patients were examined. Pre-surgery screening showed 115 (39.8\%) women with $\mathrm{AH}$, whereas 84 cases $(29.1 \%)$ showed endometrial cancer. Tissues obtained during hysterectomy were analyzed after surgery. Cancer was confirmed in $42.6 \%$ of patients (123 of 289 samples), with cancer invasion into uterine myometrium up to $50 \%$ thickness in $30.9 \%$ (38 of 123 samples) and 10.6\% (13 of 123 samples) involved the outer $50 \%$ of the myometrium. In 10 of 16 cases (62.5\%), where biopsy findings were inconclusive or questionable, endometrial cancer was identified in tissue samples obtained during a hysterectomy [9].

Patient age in Zhang's group varied from 34 to 88 years old, with an average of 57 . Endometrial cancer frequency in samples obtained during a hysterectomy was significantly higher in patients over 50 years old $(43.2 \%)$ than in the younger group (28.9\%) [17]. It is in line with our own results and confirms existing data claiming that endometrial cancer rate increases with age [18]. Biopsied endometrial tissue samples show complex hyperplasia with atypia in 103 cases, whereas samples obtained by endometrial curettage identify 119 cases.

Endometrial cancer was identified much more frequently in samples obtained using directed biopsy (31.1\%) than in those obtained using endometrial curettage.

Complex AH was associated with 41 cases of endometrial polyps. Complex endometrial hyperplasia not associated with endometrial polyps seems to correlate with a higher endometrial cancer rate (42.5\%) much more than a complex endometrial hyperplasia with atypia related to endometrial polyps (19.5\%) [17].

Other researchers also observed an endometrial cancer rate that is higher in cases of atypical complex hyperplasia not associated with endometrial polyps (35\%) compared to those with endometrial polyps (21\%) [19]. Mittal and Costa found that 31\% of patients with previously diagnosed complex $\mathrm{AH}$ in the proxim- ity of endometrial polyps showed endometrial cancer in post-surgical tissue samples obtained during hysterectomy [20].

There are two explanations as to why cancer is diagnosed in hysterectomy tissue samples after complex $\mathrm{AH}$ is initially confirmed in an endometrial polyp. Firstly, a polyp fragment containing cancerous cells is not completely removed while collecting endometrial samples. Secondly, adjacent endometrium contained cancerous cells but was not collected for analysis. In the second hypothesis it is worth noting that the endometrium area adjacent to the polyp can be influenced by excessive estrogen stimulation, which is a known risk for the development of polyps, endometrial hyperplasia and endometrial cancer [21].

Lacey et al. conducted a clinical control study on a group of 7947 women diagnosed with endometrial hyperplasia between 1970 and 2002. In 138 patients progression to a neoplasm was observed 6 years later on average (range from 1 to 24 years). Patients in the control group ( $n=241$ ) were matched to the experiment group in terms of age, biopsy date, lack of progression to neoplasm and duration of observation. In cases of endometrial hyperplasia without atypia accumulated risk of progression increased to $1.2 \%$ over 4 years, to $1.9 \%$ over 9 years and to $4.6 \%$ over 19 years after the confirmed diagnosis. In cases of $\mathrm{AH}$ accumulated risk progressively increased from $8.2 \%$ over 4 years to $12.4 \%$ over 9 years and to $27.5 \%$ over 19 years. Therefore, the risk of developing endometrial cancer among women with atypical endometrial hyperplasia was 21 times higher than the average population risk [13]. In a frequently cited study of Kurman et al. from 1985, where the experimental group consisted of 170 patients with endometrial hyperplasia, only in 2 of 122 (1.6\%) cases was progression to neoplasm found, in contrast to 11 of 48 cases $(23 \%)$ with $\mathrm{AH}(p=0.001)$. Patients were monitored for a period from 1 to 26.7 years (13.4 years on average). Kurman et al. recommended conservative management of endometrial hyperplasia without atypia, especially in women in perimenopausal age or after menopause [22].

On the other hand, little is known about the progression of $\mathrm{AH}$ to a neoplasm in women who are under hormonal treatment to remain fertile or to avoid hysterectomy. Moreover, all evidence-based medicine recommendations are insufficient. Current risk assessment of progression is limited to raw, insufficient and inadequate figures obtained over an unspecified period of time and limited range of examples, with a lack of control groups and inefficient analysis methods [13].

More studies point out that coexisting endometrial cancer is observed in patients with endometrial hyperplasia. Atypical endometrial hyperplasia is closely associated with progression to neoplasm or coexisting cancerous tissue in the endometrium. Chen et al. studied 
a group of 77 women who underwent hysterectomy as a consequence of endometrial hyperplasia by analyzing tissue samples obtained through uterine curettage. In 20 patients endometrial cancer was found after surgery and in 57 non-endometrial cancer was identified. Chen's study proves that factors such as menopausal status, diabetes, weight, BMI and cytological atypia influence the endometrial cancer identification rate. Final histopathological results in all women with coexisting endometrial cancer showed histological grades 1 and 2 [23]. Our own post-surgery results show mostly (67.93\%) well-differentiated cancer grades. A moderately differentiated grade is seen in $18.86 \%$ of cases and poorly differentiated in only $1.89 \%$. Such results are consistent with previous research findings [24, 25].

A relatively high percentage of undiagnosed or dormant cancer cases may partially result from techniques used to collect samples. During biopsies or curettage only a selected part of the endometrium is collected, and in other cases the operator might have insufficient experience [26]. An insufficient sample volume collected during the diagnostic process can result in only one part of a given cancer being examined before surgery $[6,16,27,28]$. In addition, a vast number of blind procedures are a failure due to improper technique, and the collected sample has no diagnostic value due to inadequate quality and/or quantity [29, 30].

Failed diagnosis can also be a result of a situation where the samples are collected from insufficient tissue depth. Such samples when tested may contain only a superficial, better differentiated cancer part, whereas deeper parts might contain more malignant cancerous cells [26, 31]. According to Epstein et al., samples collected during curettage in women with post-menopausal bleeding and endometrial thickness of $\geq 5 \mathrm{~mm}$ show undiagnosed polyps (58\%), complex endometrial hyperplasia with atypia (60\%) and endometrial cancers (11\%) [32].

Risk of developing a malignant cancer cannot be accurately determined as it ranges from $0 \%$ to $27 \%$ for endometrial hyperplasia without atypia and $20 \%$ to $100 \%$ with $\mathrm{AH}$. It can be attributed to poor and inaccurate diagnostic analysis performed by pathomorphologists in pathomorphology laboratories, but also to the clinical and pathological heterogeneity associated with $\mathrm{AH}$. Mitchard and Hirschowitz described the influence of inaccurate risk determination on the accuracy of histopathological findings [33].

In summary, the frequency of coexisting endometrial cancer in patients with endometrial hyperplasia diagnosed before surgery was at a high of $88.68 \%$. The relatively high frequency of well-differentiated cancers (G1 - 67.93\%) and stage IA cancers (84.79\%) may suggest a relatively good prognosis. Apart from cytologic atypia, age was the main risk factor for coexisting cancer in patients with endometrial hyperplasia. Atypical hyperplasia can be successfully treated with progestagens, as recommended and suggested in the literature. However, hysterectomy is advised in post-menopausal women with cytologic atypia due to higher risk of potential coexisting cancer or the risk of subsequent progression to neoplasm.

\section{Conclusions}

Research findings suggest that histopathological pre-surgery diagnosis of an $\mathrm{AH}$ is not confirmed after surgery in the majority of cases. Histopathological tissue analysis identified cancer in $88.86 \%$ of examined patients. In is therefore advisable to qualify patients with a diagnosed $\mathrm{AH}$ for a hysterectomy due to the increased risk of a coexisting cancer or hyperplasia that can subsequently progress to a neoplasm.

\section{Disclosure}

The authors report no conflict of interest.

\section{References}

1. Chen Y-L, Cheng W-F, Lin M-C, et al. Concurrent Endometrial Carcinoma in Patients with a Curettage Diagnosis of Endometrial Hyperplasia. J Formos Med Assoc 2009; 108: 502-507.

2. Mutter GL. Endometrial intraepithelial neoplasia (EIN): will it bring order to chaos? The Endometrial Collaborative Group. Gynecol Oncol 2000; 76: 287-290.

3. Sobczuk K, Sobczuk A. New classification system of endometrial hyperplasia WHO 2014 and its clinical implications. Menopause Rev 2017; 16: 107-111.

4. Montgomery BE, Daum GS, Dunton CJ. Endometrial hyperplasia: a review. Obstet Gynecol Surv 2004; 59: 368-378.

5. Gawron I, Łoboda M, Babczyk D, et al. Endometrial cancer and hyperplasia rate in women before menopause with abnormal uterine bleeding undergoing endometrial sampling. Przegl Lek 2017; 74: 139-143.

6. Practice Bulletin No. 149: Endometrial cancer. Obstet Gynecol 2015; 125 : 1006-1026.

7. WHO Classification of Tumours of Female Reproductive Organs. Kurman RJ, Carcangiu ML, Herrington CS, Young RH (eds.). $4^{\text {th }}$ ed. International Agency for Research on Cancer (IARC). Lyon 2014; 121-154.

8. Bobin L, Malinowski A. Rozrosty endometrium - diagnostyka i leczenie. Menopause Rev 2007; 4: 212-219.

9. Trimble CL, Kauderer J, Zaino R. Concurrent Endometrial Carcinoma in Women with a Biopsy Diagnosis of Atypical Endometrial Hyperplasia. Cancer 2006; 106: 812-819.

10. Sajdak S, Markowska A, Rehlis S, Ludwin I. Histeroskopia w leczeniu oszczędzającym płodność w przypadkach rozrostów atypowych i wczesnego raka endometrium - korzyści i zagrożenia. Curr Gynecol Oncol 2016; 14: 231-236.

11. Colombo N, Creutzberg C, Amant F, et al. ESMO-ESGO-ESTRO Endometrial Consensus Conference Working Group: ESMO-ESGO-ESTRO Consensus Conference on Endometrial Cancer: diagnosis, treatment and follow-up. Ann Oncol 2016; 27: 16-41.

12. de Rijk SR, Steenbergen ME, Nieboer TE, Coppus SF. Atypical Endometrial Polyps and Concurrent Endometrial Cancer. Obstet Gynecol 2016; 128: 519-525.

13. Lacey JV, Sherman ME, Rush BB, et al. Absolute Risk of Endometrial Carcinoma During 20-Year Follow-Up Among Women With Endometrial Hyperplasia. J Clin Oncol 2010; 28: 788-792.

14. Nieminen TT, Gylling A, Abdel-Rahman WM, et al. Molecular Analysis of Endometrial Tumorigenesis: Importance of Complex Hyperplasia Regardless of Atypia. Clin Cancer Res 2009; 15: 5772-5783. 
15. Sznurkowski JJ, Knapp P, Bodnar L, et al. Zalecenia Polskiego Towarzystwa Ginekologii Onkologicznej dotyczące diagnostyki i leczenia raka endometrium. Curr Gynecol Oncol 2017; 15: 34-44.

16. Management of endometrial hyperplasia. Royal College of Obstetricians and Gynaecologists/British Society for Gynaecological Endoscopy Green-top Guideline No. 67. RCOG/BSGE Joint Guideline, February 2016.

17. Zhang C, Wang EY, Liu F, et al. Routine histologic features in complex atypical hyperplasia can predict the presence of endometrial carcinoma: a clinicopathological study of 222 cases. Hum Pathol 2018; 80: 40-46.

18. Spaczyński M. Nowotwory trzonu macicy. In: Położnictwo i ginekologia, Bręborowicz GH (ed.). PZWL, Warszawa 2010; 833-842.

19. Cramer DW. The Epidemiology of Endometrial and Ovarian Cancer. Hematol Oncol Clin North Am 2012; 26: 1-12.

20. Mittal K, Da Costa D. Endometrial Hyperplasia and Carcinoma in Endometrial Polyps: Clinicopathologic and Follow-Up Findings. Int J Gynecol Pathol 2008; 27: 45-48.

21. Zhang C, Sung J, Quddus MR. Association of ovarian hyperthecosis with endometrial polyp, endometrial hyperplasia, and endometrioid adenocarcinoma in postmenopausal women: a clinicopathological study of 238 cases. Hum Pathol 2017; 59: 120-124.

22. Kurman RJ, Kaminski PF, Norris HJ. The behawior of endometrial hyperplasia: A long-term study of untreated hyperplasia in 170 patients. Cancer 1985; 56: 403-412.

23. Chen YL, Cheng W-F, Lin M-C. Concurrent Endometrial Carcinoma in patients with a Curettage Diagnosis of Endometrial Hyperplasia. Formos Med Assoc 2009; 108: 502-507.

24. Montgomery BE, Daum GS, Dunton CJ. Endometrial hyperplasia: a review. Obstet Gynecol Surv 2004; 59: 368-78.

25. Merisio C, Berretta R, De loris A, et al. Endometrial cancer in patients with preoperative diagnosis of atypical endometrial hyperplasia. Eur J Obstet Gynecol Reprod Biol 2005; 122: 107-111.

26. Cwonda Ł, Wójcik-Krowiranda K, Michalski T, et al. Analiza wyników badań histopatologicznych materiału przed- i pooperacyjnego w nabłonkowych nowotworach złośliwych błony śluzowej trzonu macicy. Curr Gynecol Oncol 2017; 15: 105-112.

27. NCCN Clinical Practice Guidelines in Oncology (NCCN Guidelines): Uterine neoplasms. Version 1.2017 - November 21, 2016. Available from: https://www.nccn.org/professionals/physician_gls/pdf/uterine.pdf.

28. Bourdel N, Chauvet P, Tognazza E, et al. Sampling in atypical endometrial hyperplasia: which method results in the lowest underestimation of endometrial cancer? A systematic review and meta-analysis. J Minim Invasive Gynecol 2016; 23: 692-701.

29. Ludwin A, Pityński K, Szczudrawa A, et al. [Value of saline infusion sonohysterography and hysteroscopy in postmenopausal patient with persistent abnormal ultrasonographic images after endometrial curettage with normal histological results]. Ginekol Pol 2003; 74: 786-792.

30. Spiewankiewicz B, Stelmachów J, Sawicki W, et al. The effectiveness of hysteroscopic polypectomy in cases of female infertility. Clin Exp Obstet Gynecol 2003; 30: 23-25.

31. Ceci O, Bettocchi S, Pellegrino A, et al. Comparison of hysteroscopic and hysterectomy findings for assessing the diagnostic accuracy of off ice hysteroscopy. Fertil Steril 2002; 78: 628-631.

32. Epstein E, Ramirez A, Skoog L, et al. Dilatation and curettage fails to detect most focal lesions in the uterine cavity in women with postmenopausal bleeding. Acta Obstet Gynecol Scand 2001; 80: 1131-1136.

33. Mitchard J, Hirschowitz L. Concordance of FIGO grade of endome trial adenocarcinomas in biopsy and hysterectomy specimens. Histopathology 2003; 42: 372-378. 